\title{
TRAINING FOR FUTURE ESP TRAINERS: EVALUATING THE TRAINING OF TRAINERS (TOT) PROGRAM IN LABUAN BAJO, MANGGARAI BARAT, FLORES
}

\author{
Irfan Rifai \\ English Department, Faculty of Humanities, BINUS University \\ Jln. Kemanggisan Ilir No. 45, Kemanggisan-Palmerah, Jakarta Barat 11480 \\ irifai@binus.edu
}

\begin{abstract}
By cooperating with Yayasan Komodo Kita and Mandiri Bank, English department of Binus University was chiefly in charge of a 15 day Training Of Trainers (TOT) program for 24 participants prepared for teaching English in Labuan Bajo, Flores. The training was aimed to prepare already fluent- in - English- teachers, tour guides, and university graduates with the right tools and method in teaching English. To assess the program, a set of evaluation questionnaire was given to the participants to know their responses on the training material, the trainers, and the program by using Likert's scale type questions. An observational record was also used as a tool to measure participants' achievement. The questionnaire reveals that the participants respond positively to the program and the material and favor the approaches made by the trainers during the training. However, the training shows various results in participants' performance. It is assumed that the non teaching background of the majority of participants and the level of English as two key factors influencing their performance.
\end{abstract}

Keywords: ESP, Training of Trainers, Evaluation

\begin{abstract}
ABSTRAK
Dengan bekerjasama dengan Yayasan Komodo Kita dan Bank Mandiri, Jurusan Sastra Inggris Universitas Bina Nusantara bertanggung jawab secara penuh terhadap pelaksanaan Pelatihan untuk Pelatih (TOT) yang berlangsung 15 hari dan diberikan kepada 24 peserta yang dipersiapkan untuk mengajar Bahasa Inggris kepada masarakat Labuan Bajo, Flores. Pelatihan bertujuan untuk memberi pembekalan kepada guru, pemandu wisata, dan lulusan universitas tentang cara mengajar dan metode pembelajaran bahasa Inggris yang tepat. Untuk mengetahui respons peserta terhadap materi, pelatih dan program pelatihan, serangkaian pertanyaan diajukan dengan menggunakan pola pertanyaan skala Likert. Catatan observasi perkembangan peserta juga di gunakan untuk mengetahui ketercapaian peserta terhadap materi pelatihan. Hasil kuesioner menunjukkan bahwa peserta pelatihan merespons secara positif terhadap program, materi yang digunakan dan pendekatan yang dilakukan oleh pelatih dalam mengajar. Akan tetapi, hasil pelatihan menunjukkan bahwa peserta menunjukkan pencapaian yang berbeda. Diasumsikan bahwa latar belakang sebagian peserta dan bervariasinya level kemampuan bahasa Inggris mereka menjadi faktor yang memengaruhi bervariasinya pencapaian peserta.
\end{abstract}

Kata kunci: ESP, Training of Trainers, Evaluation 


\section{INTRODUCTION}

Labuan Bajo is a town located in Manggarai Barat, Flores. Being close to Komodo island, which was crowned as the new 7 wonder in 2011, Labuan Bajo has a very promising potential as a tourist attraction. However, one of the hazards mentioned by many foreign visitors was the ability of the local people to communicate in English. This has become a concern for the local government. And for the reason of improving the local's ability in communicating in English, we were invited to take part in a program called TOT, which was specially made to bridge the aim of the local government to make its local people speak English.

The program was subsequently followed by 24 participants coming from various background and professions. Initially targeting fluent speakers of English as participants, we eventually accepted them on the basis of 'commitment' instead of 'English competence'. Lasted for 15 sessions, the program offers opportunities for the students to design materials for their teaching, try them on and use them to teach in micro teaching settings. It was expected that they would use approaches introduced to them in the 15 sessions.

The training program was somewhat applying most of Murphy's Workshop Procedures (1995), which involve four steps: trainees play the roles as students, trainees in group work, trainees' presentation and critical appraisal made by the trainers. The materials were constructed based on the basic English teaching theories, such as ones offered by Freeman (2010). Trainees were introduced from the oldest to the most current language teaching method. However, stress was given on a communicative language teaching approach. This is in line with Homutova's he primary goal of the ESP course, which is to teach professional communicative competence that is the ability to communicate in English according to the situation, purpose and specific roles of the participants. The training program was built on the foundations for accurate communication. It goes beyond the learner’s grammatical, lexical and functional skills (Homutova, 1999 in Arestova, 2006).

Literature on ESP and Teachers' Trainings mostly circle around the trends, the problems, the course design and the effectiveness of some programs. Basturksmen (2006) claims that in the field of ESP not many books have been written on ESP teaching methodology. Basturksmen, furthermore, suggests that an ESP class should be crafted by considering three elements: The Language, The Learning and The Teaching. By them, she means that a trainer should pay attention to the syntaxes element of the training like grammar, text and the ability of producing sentences in the target language as well as the conditions and the process of learning in achieving the objectives of the lesson. Coming from these two points, a trainer can start deciding appropriate methodologies to use for the program.

In the training, the elements believed to be suitable to learn in the context of our program's objectives were put. The following is the elements of materials that we include. On session 1 , some language teaching method ranging from Grammar Translation Method to Task-Based Learning was introduced. In this session, the use of some methods and some possible roles that teachers would play in the classroom were modeled. 
Table 1 List of Topics and Session

\begin{tabular}{c|c|l}
\hline SESSION & DATES & \multicolumn{1}{c}{ TOPICS } \\
\hline 1 & 9 & Language Teaching Methodology and Teachers' Roles \\
\hline 2 & 10 & Setting the Mood \\
\hline 3 & 11 & Starting and Finishing the Lesson \\
\hline 4 & 12 & Giving Instructions \\
\hline 5 & 13 & Asking Questions \& Eliciting \\
\hline 7 & 14 & Correcting without Discouraging \\
\hline 8 & 16 & Teaching Vocabulary \\
\hline 9 & 17 & Planning Your Lesson \\
\hline 10 & 18 & Material Development \\
\hline 11 & 19 & Creating Activities \\
\hline $12 \& 13$ & $21 \& 23$ & Teaching Aids \\
\hline $14 \& 15$ & $24 \& 25$ & Final Presentation: Teaching Practice \\
\hline
\end{tabular}

Starting from session 2 - session 13, trainees were exposed with classroom- based praxis. Started with setting the atmosphere of the class up to task based learning, we encouraged everyone to work in groups and as individuals and asked them to try the activities they created in the class with their friends acting out as students. On the last two sessions, trainees were given opportunities to do teaching practices on their own. Before presenting, they had close tutorial with the trainers to prepare for the topic, teaching materials, activities and aids that they could use for teaching.

Before the training program was launched, it was soon realized that some of the trainees were experts in their field. It is referred to those who work in the tourism field. Therefore, suggestion by Sierocka (2008) was followed: the trainers became more like a language and teaching approach advisers than lecturers or instructors.

Having spent almost a month in Labuan Bajo designing materials and giving training, the trainers found some challenges that they had to cope with. First, trainees were too varied in background, English competence and motivation. Trainers were lucky that they were not too huge in numbers. Second, Materials preparation was not easy as trainers had to try to meet the expectations: both of the trainees and the foundation. Therefore, trainers came one week before the training began to interview trainees and then designed the materials. Third, it was not easy to leave some of inexperienced trainers having to teach in Komodo islands without close supports and advices.

\section{RESEARCH METHODS}

The study aims to answer the following questions. 1) How do the trainees respond to the material, trainer and the delivery of the program? 2) How did the participants perform? How did their background affect their performances during the class and in the teaching practice? And, 3) are there any correlation between trainees' responses with their teaching practice?

To answer the inquiries, a questionnaire was given to the trainees on the last day of the training to have their opinions on the program and its variables. A summary of trainers' observational record of the trainees was also used to measure trainees' performance and teaching practice. Both sources of information are then compared to see whether there are any relations between their responses with the result of their teaching practices. Participants were 24; with 7 female and 17 male participants. They are in the range of age between: 20-30, 30-45 and 1 participant who was in her 70 . They are coming from different background of jobs and English competence. 


\section{RESULTS AND DISCUSSION}

To answer the first inquiry on the trainees' response to the material, trainer and the program, a set of questions was asked. The following is the list of the questions: The first 2 questions asked trainees' opinions on training materials: "Were the training materials well organized and easy to follow?" And "How effective was the sample, case studies or teaching aids used to help you understand the materials better?"

Likerts type of scales were used to measure trainees' scale of opinions on the two questions with 1 representing the least favorable and 6 the most favorable answers. The trainees responded very positively to the questions. In question number 1, the trainees' response was 5.6 from 6 (5.6/6) for the most favorable answer. It shows that the trainees show great confidence to the materials offered in the program. In question 2, the trainees were equally very satisfied in the samples, case studies and teaching aids used in the materials. The scale of the satisfaction was 5.6 from the possibility of 6 .

The following set of questions focus on gathering the trainees' opinion on the trainers' performance in giving the training. Details of the questions are put on the left with the scores for each trainer with the total score average of the trainer reaching 5,7 out of possible 6 .

Table 2 Questions and Response on trainers

\begin{tabular}{|c|c|c|c|c|c|}
\hline No & QUESTIONS & T.A & T.B & T.C & Interpretation \\
\hline 1 & $\begin{array}{l}\text { Did the instructor (s) master the training } \\
\text { materials? }\end{array}$ & 5,9 & 5,9 & 5,75 & Yes. Very \\
\hline 2 & Did the trainers explain the materials clearly? & 5,9 & 5,8 & 5,8 & Very clearly \\
\hline 3 & Did the trainers answer your questions clearly? & 5,85 & 5,75 & 5,7 & Very clearly \\
\hline 4 & $\begin{array}{l}\text { Did the trainers keep you attracted to the whole } \\
\text { training sessions? }\end{array}$ & 5,81 & 5,9 & 5,6 & $\begin{array}{l}\text { We are very } \\
\text { attracted }\end{array}$ \\
\hline 5 & $\begin{array}{l}\text { How relevant were the examples and the models } \\
\text { given by the trainers? }\end{array}$ & 5,66 & 5,6 & 5,6 & Very relevant \\
\hline \multirow[t]{3}{*}{6} & How effective was the trainers manage their time? & 5,71 & 5,75 & 5,7 & Very effective \\
\hline & Total for each trainer & 5,77 & 5,77 & 5,68 & \\
\hline & TOTAL AVERAGE & & 5,74 & & \\
\hline
\end{tabular}

From the table it can be concluded that the trainees seem to have high confidence on the performance of the trainer. From scale 1 to 6 , not one of the trainer received any scale lower than 5, 6 . From both set of questions on the material and the trainers, it is recorded that the trainees show a very significant level of satisfaction on the both the materials and the performance of the trainers.

The trainees also respond positively to the questions on the training. The questions: "How relevant is the training with your current/future job? Was receiving 5,5 scale. The following question: Do you find the training useful? , receives the most positive feedback, in which almost $100 \%$ trainees believe that the training was totally useful for them. The scale was 5, 9 out of 6 . In the question How much new information that you got from the training?, receives 5,4 in average. It happens because there are some teachers who have probably have quite similar materials or training in the past. The last question on training was How effective was the training delivered, over all?" receives 5, 7 in average, which means that the majority of the trainees are confident that the training was effectively delivered. 
Table 3 Questions and Responses on the program

\begin{tabular}{|c|c|c|c|c|c|c|c|c|}
\hline \multirow{4}{*}{$\begin{array}{l}\text { Did the program meet your } \\
\text { expectations? }\end{array}$} & \multirow{3}{*}{ Yes } & 6 & 5 & 4 & 3 & 2 & 1 & \multirow{3}{*}{ Not at all } \\
\hline & & 14 & 4 & 1 & 0 & 0 & 0 & \\
\hline & & 84 & 20 & 4 & 0 & 0 & 0 & \\
\hline & \multicolumn{7}{|c|}{5,684210526} & \\
\hline \multirow{4}{*}{$\begin{array}{l}\text { Were the facilities and media } \\
\text { satisfying ? (room, layout, sound, } \\
\text { lighting, comfort, etc)? }\end{array}$} & \multirow{4}{*}{ Very satisfying } & 6 & 5 & 4 & 3 & 2 & 1 & \multirow{4}{*}{$\begin{array}{l}\text { Not } \\
\text { satisfying } \\
\text { at all }\end{array}$} \\
\hline & & 7 & 10 & 1 & 0 & 1 & 0 & \\
\hline & & 42 & 50 & 4 & 0 & 2 & 0 & \\
\hline & & \multicolumn{6}{|c|}{5,157894737} & \\
\hline \multirow{5}{*}{$\begin{array}{l}\text { How effective did you find the } \\
\text { means and the infrastructure during } \\
\text { the program? (accomodation, meal, } \\
\text { snack, coffee break, etc)? }\end{array}$} & \multirow{4}{*}{ Very good } & 6 & 5 & 4 & 3 & 2 & 1 & \multirow{4}{*}{ Very bad } \\
\hline & & 10 & 4 & 4 & 0 & 1 & 0 & \\
\hline & & 60 & 20 & 16 & 0 & 2 & 0 & \\
\hline & & \multicolumn{6}{|c|}{5,157894737} & \\
\hline & \multicolumn{2}{|l|}{ AVERAGE } & \multicolumn{5}{|c|}{5,33} & \\
\hline
\end{tabular}

With the last three questions on the program, trainees were still responding positively to the questions. Fourteen trainees believe that the program really met their expectation with 4 agree that it has met their expectations. However, unlike the previous set of questions, at this category of questions there was one trainee who was not really happy with the program. This question gets 5,6 scale score.

The second question on the facilities and infrastructures even receive the lowest scale score. With 5,1 , it is basically the lowest response that we have received from the trainees. Even though it stays in scale 5 area, there are 7 trainees who were not so impressed with the facilities, media and the infrastructures that we used during the training. The training took place in a vocational school, with electric fans and projector and white board. With the floor being carpeted, both trainers and trainees had to take their shoes off.

Despite the positive responses, however, how did the participants perform? How did their background affect their performances during the class and in the teaching practice? As it has been mentioned, trainees were coming from various background. To teach them, therefore, was a challenge. Apparently, this is not a new issue. Rahman, F. Et.al (2011) underlie that as trainers, ones should be ready with the difficult tasks of preparing new teachers and helping the new teachers become better experienced. These tasks range from motivating, assessing, developing their knowledge and skills, giving them experience and letting them develop under guidance or without guidance.

Having realized the challenge, the trainers went on with the training. Trainees were given a lot of input and feedback since session 1 and were asked to perform a teaching demo starting on session 14 through 15 . The following table is the result/ the scoring of students' teaching performance: 
Table 4 Teaching demonstration Scoring

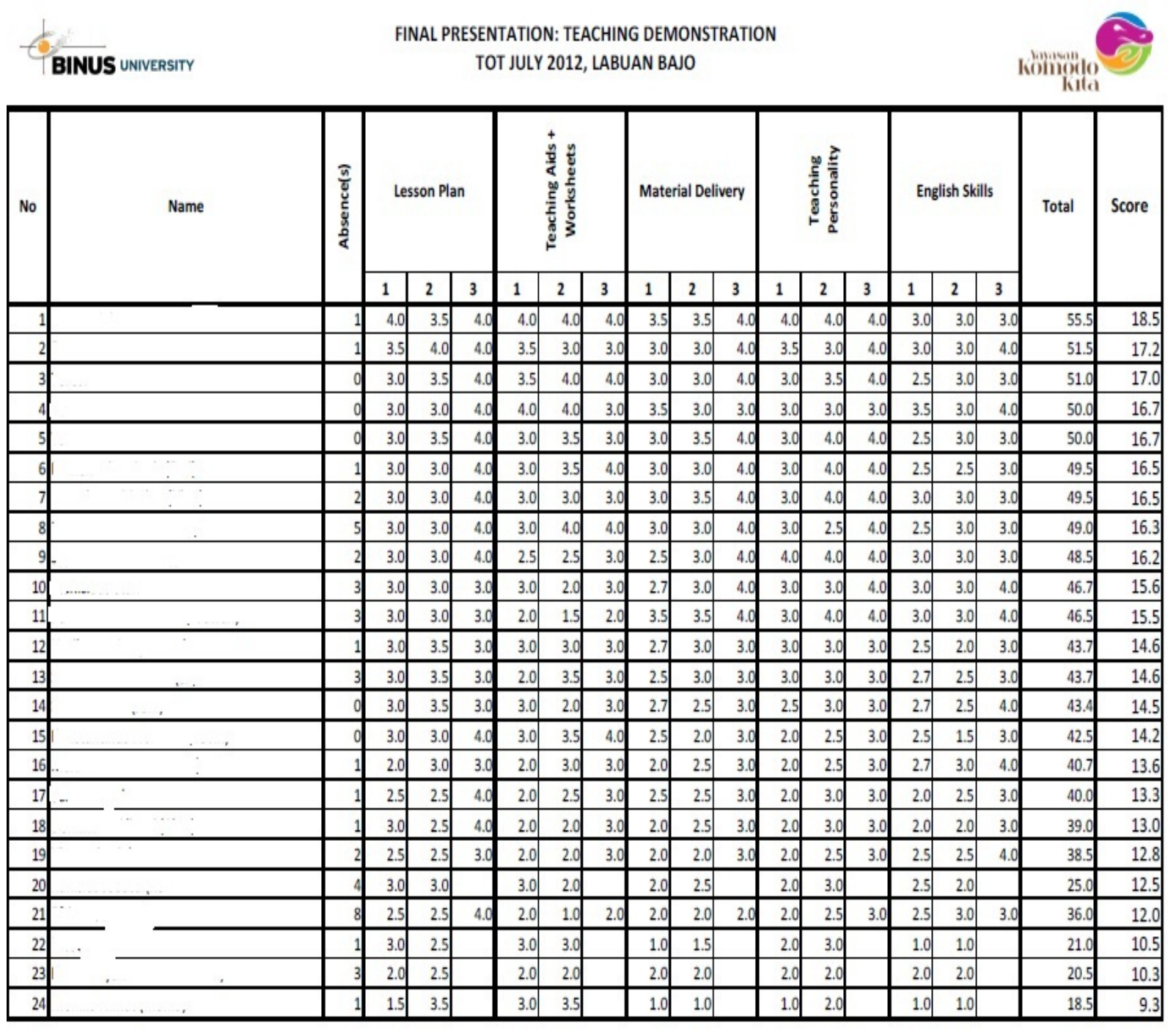

To assess the performance of the trainees during and after the training, the participants were asked to perform a teaching demo in which they were assigned to prepare a lesson plan, teaching aids and possible media to teach English. The assessment team involving: Wiwik WA, YS (Binus University) and DR (an English teacher based in Labuan Bajo). There were 5 components used for scoring: Lesson Plan, teaching Aids \& Worksheet, Material Delivery, Teaching Personality and English Skills.

The trainees are marked by using $1-4$ scales with the definitions; $1=$ poor, $2=$ average, $3=$ good, and $4=$ excellent. The assessment team, in the end, came up with 3 recommendations to the foundation: 12 trainees are ready to teach; 8 trainees are ready to teach, yet, will need some support in communicative teaching. It means this group of trainees should not teach independently on his own; 1 trainee is ready to teach with some support in English skills; and 3 trainees are ready to start being a teacher's assistant.

The question is then, who are these trainees? What made them perform or not perform? Is it their background? Analysis is made on the background and trainees' daily performance's observation. 
Table 5 Background and Trainees’ Daily Performance

\begin{tabular}{|c|c|c|}
\hline \# Trainee & Score & Background and analysis \\
\hline 1 & 18.7 & $\begin{array}{l}\text { Is an English teacher and was graduated from a teacher's college in Surabaya. Very } \\
\text { determined and very much engaged with the activities of the class. She likes sharing } \\
\text { with the rest of the class and very well prepared before teaching. Her English skill is } \\
\text { 'high intermediate'. She is at her mid 30's. }\end{array}$ \\
\hline 2 & 17.2 & $\begin{array}{l}\text { Is a calm and confident English teacher working in the vocational school we used for } \\
\text { the training. His English skill was above average. He learns quickly and could recall } \\
\text { his own teaching experience with the materials we introduced. He is at his mid 30's. }\end{array}$ \\
\hline 3 & 17.0 & $\begin{array}{l}\text { Is a graduate of a nursing school. She has always been enthusiastic during lessons and } \\
\text { was a willling participant. Her teaching prepartion was very good and she was not } \\
\text { afraid to try and ask. She is at her mid 20's. }\end{array}$ \\
\hline 4 & 16.7 & $\begin{array}{l}\text { Is one of the most senior English teachers in the class. She has had the tendency to be } \\
\text { reluctant to change, yet, gradually adopted the new ides of teaching. She is at her mid } \\
40 \text { 's. }\end{array}$ \\
\hline 5 & 16.7 & $\begin{array}{l}\text { Is still on her } 5 \text { th semester of university. She is taking English education and she } \\
\text { manages to relate her university classroom experience with the experience she has in } \\
\text { the class. She is at her early } 20 \text {. }\end{array}$ \\
\hline 6 & 16.5 & $\begin{array}{l}\text { Is an exciting character to be around. She is always positive, cheerful and is ready to } \\
\text { try new things. She is a receptionist for a diving tools shop. }\end{array}$ \\
\hline 7 & 16.5 & $\begin{array}{l}\text { Is on his last semester taking English education. He likes asking questions and } \\
\text { particpates well in discussions. He tunes to the activities well too. He is } 23 \text { years old. }\end{array}$ \\
\hline 8 & 16.3 & $\begin{array}{l}\text { Is another English teacher who had to skip some lessons for family reasons. His } \\
\text { teaching practice was pretty good. Better preparation would have made it better. He is } \\
\text { at his mid } 30 \text {. }\end{array}$ \\
\hline 9 & 16.2 & $\begin{array}{l}\text { Is an English teacher who is keen to participate and learn anything new. He is well } \\
\text { prepared and has some ideas that he was too afraid to share, sometimes. He is at his } \\
\text { mid } 30 \text {. }\end{array}$ \\
\hline 10 & 15.6 & $\begin{array}{l}\text { Is a diver whose English skill is above average. He has a very positive attitude to the } \\
\text { training and is poleased to be part of the trainees. He only intends to teach English in } \\
\text { the diving area. }\end{array}$ \\
\hline 11 & 15.5 & $\begin{array}{l}\text { Is a graduate of teacher's training college who is not sure to choose teaching as a } \\
\text { profession. He speaks English well, yet, he needs to prepare his class and lesson plan } \\
\text { better. He is at his mid } 30 \text {. }\end{array}$ \\
\hline 12 & 14.6 & $\begin{array}{l}\text { Is a non English teacher but is very keen to participate in all activities. He is close to } \\
30 \text { years old and a bright teacher. He needs some more experience in teaching english. }\end{array}$ \\
\hline 13 & 14.6 & $\begin{array}{l}\text { Is a good public speaker yet not having enough background in teaching. His English } \\
\text { needs to be improved as well. He is at his 30’s. }\end{array}$ \\
\hline 14 & 13.6 & $\begin{array}{l}\text { Is a graduate from philosophy class in a university. Learning the concept of langauge } \\
\text { teaching si somethin new for him. Therfore, he had to struggle to cope with } \\
\text { communicative language teaching concept. His English is quite good. }\end{array}$ \\
\hline 15 & 13.3 & $\begin{array}{l}\text { Is a quiet trainee. He is at university and an eager learner. He needs to improve his } \\
\text { understaning on the teaching methodology concept. He is at his early } 20 \text {. }\end{array}$ \\
\hline 16 & 13.0 & $\begin{array}{l}\text { Is a graduate from philosophy class in a university. Learning the concept of langauge } \\
\text { teaching si somethin new for him. Therfore, he had to struggle to cope with } \\
\text { communicative language teaching concept. He has had the experience of living in an } \\
\text { English speaking country. His English is quite good. }\end{array}$ \\
\hline 17 & 12.8 & $\begin{array}{l}\text { Is a quite passive participant, yet, a regular one. She still needs some experiences to } \\
\text { teach English. }\end{array}$ \\
\hline 18 & 12.5 & $\begin{array}{l}\text { Is a quiet non English department University student. He seems to struggle to } \\
\text { understand the concept of teaching and needs to improve his teaching personality. }\end{array}$ \\
\hline 19 & 12.0 & $\begin{array}{l}\text { Joining only in the last } 5 \text { sessions, he has not had enough know how to prepare for his } \\
\text { teaching practice. Even when his English was not that bad. }\end{array}$ \\
\hline 20 & 10.5 & $\begin{array}{l}\text { Is one of the trainees who never skipped classes. His cheerful manner was always } \\
\text { entertaining. However, with his imited English skills, he has to work hard to become a } \\
\text { teacher. }\end{array}$ \\
\hline
\end{tabular}




\begin{tabular}{ccl}
\hline 21 & 10.3 & $\begin{array}{l}\text { Was a fishermen turning a tour guide. Originally from Komodo island, he learns } \\
\text { English from his surroundings. Eventhough he is a very confident person, but he } \\
\text { needs to improve his English. } \\
\text { Is the oldest among us. She is a retired civil servant and has never become a teacher. } \\
\text { Her main motivation was to motivate her younger Labuan Bajonese. }\end{array}$ \\
\hline
\end{tabular}

The table shows that the top ten trainees are: 5 English teachers ( 3 males, 2 female), 1 nurse (female), 1 diver (male), 1 receptionist (female), 2 university students (1 male, 1 female). The data may not suggest gender bias. But taking from here, we can conclude that English competence plays a big role in supporting their performance of teaching.

\section{CONCLUSION}

It is not easy to prepare for a training program. Steps like needs analysis, curriculum and material development have to be done thoroughly in the time carefully planned. Having varied background of participants is certainly not a new issue. To prepare for the worst, one should be able to cater all the needs of the participants in order to get the best result that they can get. In the context of TOT program in Labuan Bajo, we were so lucky that even the participants were various in English competence and motivation, but the attitude of most trainees were positive and everybody was so supportive in creating a learning atmosphere.

The positive attitudes were shown on their responses in the questionnaire we asked them to fill on the last day of the program. The materials, the trainers, the training and the program all received above 5 (of 6) scale average of the trainees' response. Their teaching performance, however, has been pretty average. Many of them did not perform very well due to lack of good English and understanding of the concept. Short duration of the training is understood to be another factor that contributes to the performance of the trainees. It is suggested that more time is given to do coaching and close field observation to the trainees' real teaching practices.

The positive attitudes of the participants on the training program in Labuan Bajo , all in all, is not correlated with their teaching performance. Their positive responses to the survey probably only points at a fact that in a place like Labuan bajo, where trainings are not always available and opportunities are not always offered, people really appreciate other people coming to share our praxis and new ideas.

\section{REFERENCES}

Al-Wreikat, Y.A.A.S. \& Abdullah, M.K.K.B. (2010). An Evaluation of Jordanian EFL Teachers' inservice Training Courses Teaching Technique Effectiveness. English Language Teaching, 3, (4), December 2010.

Basturksmen, H. (2006). Ideas and Options in English for Specific Purposes. London: Lawrence Erlbaum Associates.

Doff, A. (1995). Teach English : training course for teachers: trainer's handbook. Cambridge, UK: Cambridge University Press. 
Freeman, D. L. (2010). Techniques and Principles in Language Teaching. Oxford, UK: Oxford University Press.

Murphy, A. R. (1995). From Practice to Performance: A manual teacher training workshop activities. Washington D.C: ELPD.

Rahman, F., et. al (2011) Relationship between Training of Teachers and Effectiveness Teaching. International Journal of Social Business and Science, 2, (4); 3, 2011.

Sierocka, H. (2008). The role of the ESP teacher. Business English, 2 (56), 2008. Available at http://www.jezykangielski.org/theroleoftheespteacher.pdf retrieved on August 28th, 2012. 